\title{
History of Medicine
}

\section{CONTRIBUTION OF AL-BERUNI IN BIOLOGY}

\author{
Prof. M.S. Khan
}

Abu-Al-Raihan Muhammad Ibn Ahmad Al-Beruni was born at Khwarizm (now kwown as Khiva in Central Asia) in 973. Although he is well known to all Arabists and Indologists as a mathematician, astrơomer, physicists, geographer, naturalist, and encyclopaedist, his name is seldom found in any of the treatises dealing with the history of biology. His outstanding work entitled, 'India' is an account of the religion, philosophy literature, geography, chronology, astronomy, customs, laws and astrology of India written about the year 1030 . Wilczynski has recently pointed out that Rainow in his work entitled. 'The great scholars of Uzbekistan' published from Tashkent in 1943 called attention to the fact that Al-Beruni in his above mentioned work, expressed some views undeniably similar to the basic principles of Darwain's future theory of natural selection through the struggle for existence and survival of the fittest was already thought of by $\mathrm{Al}$-Beruni approximately 800 years before Darwin ${ }^{1}$.

Curiously enough, the very meaning and the way in which the idea dawned to him were same as Darwin's, i.e. through observation of the methods of artificial selection as applied by animal breeders. Darwin, in 1859, when his 'Origin of spectes' was published in England was apparently not aware of Al-Beruni's work since there is no mention of it in the introduction to his book nor among the data collected by him in his 'Variation of plants and animals under domestication'. It is quite understandable as the English translation of Al-Beruni's work was published by Her Majesty's Indian Office only in 1889, that is five years after Darwin's death.

In the introduction to the description of the strife that presumably took place in the previous epochs of Indian history reaching back to mythological times, Al-Beruni explains the history of mankind on general natural processes in the whole world which are concerned with four different phenomena. Firstly he deals with the steady. unlimited reproduction in the limited area of the world in the following sentences :-

"The life of the world depends upon the sowing and procreating. Both processes increase in the course of time, and this increase is unlimited whilst the world is limited." This view corresponds remarkably to the central idea of Malthus presented in 1798 on the disproportion between the increase in the rates of reproduction and means of subsistance. We know from Darwin's autobiotgraph that the Essays on population of Malthus played a directly decisive role in the conception of his theory.

Secondly, Al-Beruni continues to give the application of this principle to living beings thus; "When a class of plants or animals does not increase any more in its structure, and its peculiar kind is established as a species of its own, then each individual of it does not simply come into existence once and perish, but besides, procreates a being like itself or several together, and not only once but several times, then this will, as single species of plants or animals occupy the earth and spread 
itself and its kind, over as much territory as it can find". The idea is not far from one of the reasonings Darwin put forward to explain his theory of natural selection namely that all organisms tend to increase in number at a geometric rate.

Thirdly, in the same description, Al-Beruni adds the following passage in which one may discover the idea of artificial selection: "The agriculturist selects his corn, letting grow as much as he requires, and tearing out the remainder. The forester leaves those branches which he perceives to be excellent, whilst he cuts away all other. The bees kill those of their kind who only eat, but do not work in their bee hive".

Finally the author ends his naturalistic interpretation of what happens to mankind on the earth with these remarks; "If thus the earth is ruined or is near to be ruined, by having too many inhabitants, its Ruler - for it has a Ruler - and His all embraching care is apparent in every particle of it - sends it a messenger for the purpose of reducing the too great number and of cutting away all that is evil" - an idea very simillar to that of Darwin's survival of the fittest."

It may be concluded that in these views of Al-Beruni the basic principles of Darwin's future doctrine are undenibly to be found although they are vague and accidental and do not form any coherent theory. Nor did Al-Berunt pretend to ascribe to them any possible significance as far as their biological meaning is concerned.

\section{A1-Beruni's 'kitab-al Saydanah'}

Another monumental contribution of Al-Beruni is his Kitab al-Saydanah fl al-tibb (the book of drug knowledge) which is a piece of collection and treasure of synonyms of plants. He gives the Greak, Syriac, Persian, Hindi, Sindhi, Sigzi, Zabuli, Tirmidhi, and Khwarazamian equivalents as well as synonyms in other dialects that are no longer extant. Legends and myths associated with many a herb have been described, and a detailed information on almost all the major drugs has been given. This is the last work of his life which he left in a first draft when he was already nearly blind and in need of the help of an assistant. It is a complete dictionary in alphabetical order of the herbal drugs known to him and to his collaborator, Abu Hamid Ahmad ibn Muhammad an-Nahshai. According to Meyerhoff ${ }^{2}$, the only existing MS of this book is in the library of the Kurshunu Cami at Bursa in Turkey. This entire work comprising upwards of 900 articles was edited by Kraus and Meyerhoff ${ }^{3}$ in 1942 . Hakim Mohammad Said ${ }^{4}$, who edited an English translation and comprehension annotation published in two volumes, oplnes that there are manuscripts of this work also in Cairo and Baghdad. Among the hundreds of articles, several are very original and unique in observation. The article on tea is lost in the Arabic original but exists only in the Persian translation and in an abridged retranslatioin into Arabic.

Another remarkable observation is related to a plant called camel thorn (Alhagd mauroruml a species found in desert regions from North Africa to central Asia. After giving a detailed description of the plant, the account says:

"In its leaves is a special feature. namely that they are contracted to form a hollow in which is generated an animal (insect) with a flattened head; when it (the leaf) is opened, it (the insect) leaps forth. I do not know to which species it belongs: it is this creature from which is yielded the manna (tranjubin) in some countries'. A kind of 
Manna is a saccharine exudation from a number of different plants belonging to various plants families. The particular manna referred to here is the one produced on the camel thorn called Alhagi manna which is known as taranjubin (honey-dew) in Persian. There are references to manna in the Holy Guran at three places 12.57. 7.160 and 20.80-81) as providential food to Israelites. Al-Beruni's observation is of extraordinary interest as it does mention for the first time, a manniparous insect. It was only in 1822, that is about 800 years after that, Burckhardt in his Travels in Syria and Holy Land' published the observations of one Capt. Frederick from India regarding three kinds of insects-responsbile for the production of manna on certain plants. Then in 1929 Ehrenberg and Hemprich reported about the cochineal insect which is now called Gossyparia mannifera. thought to provoke the exudation of manna on tamarisk trees of SInal peninsula. ${ }^{5}$

Al-Beruni in two other articles of his drug book, quotes al Fazari, in the article Taranjabin. who says that manna is like the falling of dew and called in Arabic shuhd (honey). He further quotes a certain Persian, Muhammad as-Suqabadi who says, "The manna fell on the lsraelites like snow, and it is said, like pounded bread, and it is said that it is the alhagi-manna (taranjubinl".

By these remakable observations by Al-Beruni, one is struck with admirations at his universal erudition, the critical spirit, love of truth and the intellectual courage which are so evident from the pages of Kitab al-Savdana. There is no wondef George Sarton, the great Historian of science described Al-Berunt as "one of the very greatest scientists of islam, and all considered, one of the greatest of all times." .

Al-Beruni died in 1050 (according to Meyerhof) ${ }^{6}$ at Ghazna in South Afghanistan.

\section{References}

1. Wilczynski, J.Z. on the presumed Darwinism of Al-Beruni eight hundred years before Darwin. ISIS 50 (4) : 459 (1957).

2. Meysrhof, M. The earlist mention of a manniparous insect. ISIS $=37: 32$ (1974)

3. Meyerhof, M. Ibid

4. Hakim Mohammad Sald (ed.) Al-Berunis book on pharmacy and materia medica P. vi (1973) Hamdard National Foundation, Karachi

5. Meyrhoff, M. ibid.

6. Meyerhof, ibid. 